УДК: 655.55:303.433.2

DOI: 10.26697/ijes.2019.2.53

\section{Рецензія на монографію "Професійна підготовка майбутніх фахівців соціальної галузі до профілактики дезадаптації учнів”, автор Костіна В. В.}

Професор Дмитренко Т. О. (рецензент) ${ }^{1}$

${ }^{1}$ Херсонський державний університет, Украйна

Рецензія:

Прорецензовано монографію 3 професійної підготовки майбутніх фахівців соціальної галузі до профілактики дезадаптації учнів з огляду на сучасні вимоги до підготовки фахівців.

Видавництвом ХОГОКЗ надруковано монографію Костіної В. В. на тему: "Професійна підготовка майбутніх фахівців соціальної галузі до профілактики дезадаптації учнів у різних соціальних інституціях". Роботу призначено для фахівців соціальної сфери, що готують фахівців соціальної галузі.

Сучасні реалії життя суспільства вимагають від фахівців соціальної галузі не тільки глибокого опанування історії та теорії соціального виховання особистості та практики соціальної допомоги населенню, а й високого рівня соціальної активності та досвіду здійснення професійної діяльності. 3 огляду на вищезазначене, рецензоване видання $\epsilon$ актуальним, оскільки автором запропоновано власну систему професійної підготовки фахівців соціальної галузі, яка поєднує можливості навчальної, виховної та науководослідної діяльності майбутніх соціальних педагогів i соціальних працівників у межах освітньо-професійного простору на базах закладу вищої освіти та закладів партнерської мережі інституцій, які здійснюють профілактику дезадаптації учнів, що забезпечує розвиток усіх вищезазначених професійних характеристик фахівців. Під час обгрунтування змісту освітньої діяльності 3 майбутніми фахівцями соціальної галузі до профілактики дезадаптації учнів дослідницею проаналізовано робочі навчальні плани, програми професійної підготовки майбутніх соціальних педагогів і соціальних працівників, навчальні підручники та посібники, що забезпечують підготовку фахівців у зазначеному напрямі. Безумовно цінним $є$ здійснений авторкою контентаналіз закордонного досвіду професійної підготовки майбутніх соціальних педагогів i працівників до профілактики дезадаптації учнів.

Для практиків соціальної галузі корисним буде, на наш погляд, здійснений дослідницею аналіз вітчизняного та закордонного досвіду надання соціально-профілактичних послуг учням, що дозволив авторці виокремити особливості професійної діяльності з профілактики дезадаптації учнів у системі різних соціальних інституцій, побудувати мережу їх партнерської взаємодії, розробити інваріантну модель технології роботи 3 профілактики дезадаптації учнів (Костіна, 2018, c. 47), що містить низку послідовних етапів у роботі фахівців та передбачувані результати на кожному з них.

Здійснений авторкою аналіз сучасних наукових досліджень та практики професійної підготовки майбутніх фахівців соціальної галузі до профілактики дезадаптації учнів дозволив розробити відповідну структурно-функціональну модель системи професійної підготовки (Костіна, 2018 , с. 332 ), яка відображає методологічні (мета, методологічні підходи та наукова парадигма), теоретичні (змістовно-технологічне наповнення професійної підготовки) та кваліметричні (критерії, показники професійної готовності фахівців до профілактики дезадаптації учнів за певними рівнями та методики їхнього вимірювання) засади професійної підготовки.

Проблему професійної підготовки майбутніх фахівців соціальної галузі до профілактики дезадаптації учнів розглянуто системно, виявлено взаємозв'язки та особливості у підготовці майбутніх соціальних педагогів i соціальних працівників, які мають здійснювати координацію діяльності різних фахівців соціальної сфери 3 метою комплексного розв'язання проблем учнів у різних соціальних інституціях.

Схвалення заслуговує наведене у четвертому розділі технологічне і методичне забезпечення, що дозволяє реалізувати розроблену автором модель системи професійної підготовки майбутніх соціальних педагогів і соціальних працівників до профілактики дезадаптації учнів. Особливо цінним, на наш погляд, $\epsilon$ використання автором у якості одного із провідних шляхів у професійній підготовці майбутніх соціальних педагогів i соціальних працівників до профілактичної роботи зі вразливими контингентами етнопедагогічних засобів, що дозволяють гармонізувати відносини у близькому оточенні учнів, забезпечують підвищення їхнього загальнокультурного та особистісного потенціалу, формування просоціальної поведінки.

Теоретико-методологічна i практична спрямованість монографії зумовлюють іiі актуальність для забезпечення якісної підготовки майбутніх фахівців соціальної галузі. Теоретичні обгрунтування, висновки і пропозиції становлять значний інтерес як для науки, так і для практики.

\section{Література:}

Костіна В. В. Професійна підготовка майбутніх фахівців соціальної галузі до профілактики дезадаптації учнів у різних соціальних інституціях: монографія. Харків: ХОГОКЗ, 2018. 364 с. doi:10.26697/9786177089024.2018

\section{Інформація про рецензента:}

Дмитренко Тамара Олександрівна - доктор педагогічних наук, професор, професор кафедри соціальної роботи та соціальної педагогіки, Херсонський державний університет, Херсон, Україна.

\section{Email Рецензента:}

kattyfun@ukr.net 